\title{
HEALTHY LIVING OF CHILDREN OF MOTHERS WHO WORK IN RECYCLING: DIFFICULTIES AND POSSIBILITIES ${ }^{1}$
}

\author{
VIVER SAUDÁVEL DE FILHOS DE MÃES RECICLADORAS: \\ DIFICULDADES E POSSIBILIDADES
}

\section{Giovana Batistella Mello ${ }^{2}$, Amanda Ruiz Forgiarini ${ }^{3}$, Carine Pelegrini Bissacot ${ }^{4}$, Nathália Hoffmann Adames ${ }^{5}$ e Dirce Stein Backes ${ }^{6}$}

\begin{abstract}
Objective: To understand the meaning of healthy living and, in a second step, to expand the possibilities of healthy living for children of mothers who work in recycling, based on systematic interventions at an Association of Recyclable Materials. Methodology: This is a research-action, developed between August/2019 and December/2019, in an Association of Recyclable Materials, located at the central region of Rio Grande do Sul, through systematic interventions promoting health. Results: It was evidenced that mothers who work in recycling are unable to promote healthy living for their children due to overworking and low financial income, which interferes with early weaning and creates a fragile bond between mother and child. Final considerations: The interventions allowed the expansion of the possibilities of healthy living of children of mothers who work in recycling, considering the improvement of theoretical and practical themes and the social empowerment of the mothers.
\end{abstract}

Keywords: Bond, Early weaning, Low income, Recyclers, Vulnerabilities.

\section{RESUMO}

Objetivo: Conhecer o significado de viver saudável e, num segundo momento, ampliar as possibilidades de viver saudável de filhos de mães recicladoras, a partir de intervenções sistemáticas em uma Associação de Materiais Recicláveis. Metodologia: Trata-se de uma pesquisa-ação, desenvolvida entre agosto/2019 e dezembro/2019, em uma Associação de Materiais Recicláveis localizada na região central do Rio Grande do Sul, por meio de intervenções sistemáticas de promoção da saúde. Resultados: Evidenciou-se que as mães recicladoras são incapazes de promover uma vida saudável para os filhos devido ao excesso de trabalho e à baixa renda financeira, o que interfere no desmame precoce e no vínculo frágil entre mãe e filho. Considerações finais: As intervenções realizadas, de forma sistemática e construtivista, permitiram ampliar as possibilidades de viver saudável de filhos de mães recicladoras, tendo em vista o aprofundamento de temáticas teórico-práticas e o empoderamento social das mães.

Palavras-chave: Baixa renda, Desmame precoce, Laços, Recicladora, Vulnerabilidades.

\footnotetext{
${ }^{1}$ Trabalho de Iniciação Científica - PROBIC/CNPq da Universidade Franciscana - UFN.

${ }^{2}$ Acadêmica de Enfermagem e Bolsista de Iniciação Científica da Universidade Franciscana - UFN. E-mail: giovanamello20@, outlook.com

${ }^{3}$ Acadêmica de Enfermagem e Bolsista voluntária de Iniciação Científica da Universidade Franciscana - UFN. E-mail: mandiruiz@hotmail.com.br

${ }^{4}$ Estudante do curso de Enfermagem e bolsista voluntária de iniciação científica da Universidade Franciscana - UFN. E-mail: cabissacot@gmail.com

${ }^{5}$ Odontóloga. Aluna do Mestrado Profissional em Saúde Materno-Infantil da Universidade Franciscana - UFN. E-mail: natiadames@gmail.com

${ }^{6}$ Doutora em Enfermagem. Professora do Curso de Enfermagem da Universidade Franciscana - UFN. Orientadora do trabalho. E-mail: backesdirce@ufn.edu.br
} 


\section{INTRODUCTION}

The collectors who oversee the management of products discarded by society live, every day, in poor conditions of work, housing, and health. Moreover, they are exposed to biological, physical, chemical, and biomechanical agents, beyond the social and aesthetical issues due to the garbage smell (RODRIGUES, 2017).

Recycling is a way of reusing materials that were going to be discarded like trash in an artisanal or industrial manner. This kind of work demands an improvement of new techniques to recycle materials from the workers and, this way, it promotes the creation of new products (CORREIA; ANDRADE; LIMA, 2016).

Healthy living was conceptualized and validated by the Study and Research Group in Social Entrepreneurship and Health (abbreviated into GEPESES in Portuguese), as a singular, circular, and interactive process boosted by the experiences of order and disorder, in the search for a continuing individual, familiar, and social self-organization (BACKES et al., 2016).

Having this in mind, it becomes necessary to have health professionals and health students commit themselves through activities in all contexts in which the workers from the association are inserted, and this association is the place where the data was collected. It is essential to stimulate care management for these workers, both in their work and their families; to support them in all dimensions (physical, psychic, and social); to stimulate their leadership abilities and autonomy; to establish bonds and increase the process of popular education in health, thinking in contributing to the healthy living process (BACKES et al., 2016).

Women who work in recycling are responsible, in most cases, for home livelihood, which generally results in work overload, as well as physical, mental, and social distress. Then, it is a challenge for maternity, and, therefore, compromises the mother-child bond mainly in the first two years (COSTA; ANDRADE, 2019).

The period commonly known as 1000 days comprehends conception to the child's second year of life, and it is proposed that during the first six months of life breastfeeding should be exclusive. After this period, then, should be the moment for the introduction of food and liquid to complement breastfeeding. Ensuring good nutrition will benefit the healthy development and these habits will last for a lifetime (DA CUNHA; LEITE; DE ALMEIDA, 2015).

It is understood that in these families, the mother who works in recycling is the mediator of healthy infant development. That way, children who live in vulnerable situations are more susceptible to having physical disabilities, cognitive problems, memory loss, and a lack of social skills. Faced with this issue, it is fundamental to understand the reality in which these individuals are inserted so that it is possible to build a support network and strive to bring benefits through actions that allow more adequate and safer well-being conditions (RODRIGUES, 2017). 
Based on that, this article aimed at understanding the meaning of healthy living and, in a second moment, to expand the possibilities of healthy living for children of mothers who work in recycling through systematic interventions at an Association of Recyclable Materials.

\section{METHODOLOGY}

This is a research-action, developed between August/2019 and December/2019, at an Association of Recyclable Materials located in the central region of Rio Grande do Sul, through systematic interventions of health promotion. The study was carried out in two steps: the first was observation, collection, and data analysis on the meaning of healthy living and the second was the intervention itself based on the data analyzed and discussed with the individuals from the Association.

In the first meeting, we aimed at identifying demands and strategies in the work context through observations, as well as collecting relevant data survey about healthy living on the scheduled days. Data collection was done through interviews. In the study, all individuals from the Association who could answer the interviews and who signed the free consent form were included. We excluded from the study the ones under 18 years old and those who, for any reason, did not want to be part of the research. Based on these criteria, 19 mothers from the Association of Recyclable Materials participated in the entire process.

In order to maintain the information secrecy, the participants of the research will be identified, throughout the text, by the letter "I" (interviewee) followed by a number that corresponds to the speech.

The interviews were conducted based on guiding questions such as: What do you understand by healthy living? How to expand the possibilities of healthy living? What nursing/health care strategies do you consider important for enhancing your child's healthy living, as well as other issues that have arisen in the process?

The interviews were recorded and subsequently transcribed and organized, and the material was submitted to thematic content analysis. We sought to discover the nuclei of meaning that composed the communication, whose presence or frequency added significant perspectives to the object of study.

After the analysis and discussion of the data previously collected, systematic interventions were carried out in the Association in the shape of thematic workshops, seeking to expand the healthy living of the children of mothers who are members of the recycling association. The mothers actively participated in the workshops and, in the sequence, became multipliers of this learning in their homes. The themes that were approached constructively and playfully were: breastfeeding, healthy feeding, reuse of fruits and vegetables, oral and body hygiene, sleep and rest, and mother-baby interaction.

For the analysis of the data, the discriminated steps were followed: in the pre-analysis, there was an exhausting data reading, followed by the material organization and hypothesis formulation; the material exploitation step meant codification into raw data; and the interpretation and delimitation 
of data were done through the division of the themes into categories by the understanding of meanings (BARDIN, 2011).

The interventions were carried out by scientific initiation and academic scholarship holders of the nursing course in different semesters, in partnership with a student of the Professional Master's in Maternal and Child Health of a University, located in the central region of the state of Rio Grande do Sul.

The Project was submitted and approved by the Research Ethics Committee under the $n^{\circ}$ 2.516.680.

\section{RESULTS AND DISCUSSION}

The data organized and analyzed resulted in two thematic categories: living between the real and the ideal, and showing new possibilities to healthy living from what is viable in their context.

\section{LIVING BETWEEN THE REAL AND THE IDEAL}

Mothers who work in recycling recognize that they face environmental, socioeconomic, and cultural difficulties on a daily basis, which instigates them to understand the importance of healthy living in their lives. This way, due to all these weaknesses they end up opting for what is feasible at the moment and not for what is necessary for their health, thus weakening their interactions, relationships, and individual, social, and family associations, as shown by the statements.

"There's nothing much to do, I would need to eat better to have a healthy life, sleep more. And as a recycler, there is no way to do so, because there is very little money in it." (II)

"It is not easy to have a diet at home, because we don't always have food every, because I earn around two hundred reais every two weeks, and I support myself and two kids." (I2)

It was evidenced that, based on the participants' report, these mothers who work in recycling have great obstacles concerning their health issues due to the limited view of healthy living and having to face their excessive workload and low income as their main barrier. Because of this, maternity is not integrally performed, and then, there is no possibility of a healthy and welcoming environment being provided to create bonds between mother and kids.

Because of financial difficulties, many mothers need to return to work right after their child's birth, resulting in early weaning with no possibility of choice. Besides, even going back to work does not guarantee a healthy life.

"We get very worried because we know we will earn very little and we have to pay the bills and buy things and all these things interfere in our health." (I3)

"Fruits are healthy, right? They ask for them, but I say that I do not have money to buy them." (I4) 
It is known that breastfeeding, mainly during the first six months of life, has become the most important and effective strategy for the healthy living of the child and it strengthens bonds, affection, and confidence, besides it being a complete meal. It also brings benefits such as the reduction of morbidity and mortality, and the improvement of the immune system, as well as the promotion of the mother's integral health (ROLLINS et al., 2016).

"I have a four-month-old baby, and my mother takes care of her for me to go to work, and she gives her milk flour supplements, I do not agree, but there is nothing I can do... I need to work." (I5)

"It's not easy, but I prefer to give them (kids) instead of myself. We know what is best, but...?" (I9)

"The workshops you offered really helped me... I understand some things better... but sometimes it is really difficult to do with my baby, there is lack of time, there is a lack of everything." (I13)

It can be noticed in the testimonials of the mothers from the Recycling Association that they are aware of the ideal that they wish for their kids, and, according to them, they deserve the best conditions. However, they also argue that the ideal is generally too far from reality, that is, from their economic, financial, and physical conditions.

We corroborate with authors who defend the need for thinking about social and health policies that are coherent and viable for the different existing realities. For this, health professionals must insert themselves in different scenarios so that they understand the demands of the individuals, families, and communities, in order to design prospective strategies that guarantee a possible and viable healthy living (BACKES et al., 2016; RODRIGES, 2017; LOMBA et al., 2018).

\section{SHOWING NEW POSSIBILITIES FOR A HEALTHY LIVING FROM WHAT IS VIABLE}

Based on the comprehension that the ideal, in most of the cases, is not possible to be reached by the mothers from the Association, thematic workshops were offered to allow viable alternatives that approximate, as much as possible, the ideal and the real. There was a discussion about the utilization of fruit peels, vegetable stalks, among other possible alternatives for the context.

In this discussion, the subject of the importance of using the most of each food, such as every part of beets, broccoli, and parsley, as they contain fiber and can be used and braised with beans and used in stews, and they can also enrich other dishes such as omelets. Another item that has been widely spoken about is the reuse of the banana peel, from which it is possible to make jams, cakes, and farofa. Moreover, it has a great amount of vitamin $\mathrm{C}$ and twice as much potassium as the fruit pulp. Another example is using the leftover ground meat from lunch in other dishes such as croquettes, pancake fillings, and meatloaves.

"Your explanation about reusing fruit and vegetable peels was very useful to me. I have now started to apply this to some things I have at home..." (I15)

"Many things depend on us and can be done... others are more difficult and we happen to forget. All you have said gave me some motivation to do things." (II7) 
According to the speeches, it was notable that the themes of the workshops significantly promote an approximation of the student team with mothers who work in recycling. That way, facing all the advantages of a healthy diet and the use of these supports during the workshop, one of the most difficult issues was the one about early weaning because of the routine that they have to establish to financially support their homes. It is known that this period of breastfeeding is enriching for both mother and child as it brings physiological and psychological benefits, in addition to the emotional bonds it creates (SANTOS; SCHEID, 2019).

To minimize these occurrences, the milk depletion technique was shown to mothers. According to the Ministry of Health (2015), the milk should be stored in glass containers and kept in the freezer for 15 days and then moved to the refrigerator for 12 more hours. Afterward, it should be heated in a water bath and be offered to the baby with either spoons or cups, reducing the use of bottles, and when the mothers are at home, they should breastfeed frequently. During the demonstrations, they were instructed not to increase the size of the bottle nipple, because it is the precise effort of sucking that helps the development of the orofacial muscles. Still, after breastfeeding, oral hygiene should be done with a gauze or a wet cloth with filtered water throughout the mouth, cleaning the cheeks, gums, and tongue to remove residues of milk.

The truthfulness of the discussions was analyzed in light of the assessment of the needs, but also which responsibilities should be considered as the best way to reach the set goal. As doubts arose, it was necessary to empower the interventions proposed due to the diversity among recyclers. The fundamental issue that triggered a discussion was the provision of a better quality of life through an appropriate diet. They were able to recognize the appropriate methods; however, applying them is far from their realities and it was through this lack of foundation that the conversation happened.

Due to the easy access to communication, it was possible to have more suggestions on how to introduce it into the proper daily life, considering the budget in the context in which they are inserted with their family members. One of the suggested actions was the creation of vegetable gardens, and because of this action, organic products are then established as an improvement for health, resulting in a significant cut in grocery expenses; it also helps promote a menu with seasonal foods, fruits, vegetables, and salads in a way that guarantees positive and low-cost results in greater use of products.

In order to expand the knowledge of care, some educational videos were made available in the workshops, and they encouraged habits of oral and body hygiene, sleep and rest, and mother-baby interaction, stimulating a process of transformation of habits and attitudes of mothers so that they promote autonomous behavior and awaken to a preventive awareness. The importance of adapting to meal times was determined among them as well as avoiding the consumption of drinks and foods with high sugar levels to help prevent tooth decay, diabetes, and childhood obesity. It was also possible to notice the relevance of regularity of sleep and rest and actions that promote the child's thorough development. 
It is observed, however, the necessity for professionals to establish a dialogue about formal and informal care, in an attempt to broaden interactive possibilities for the empowerment of the resources of the social actors themselves and, above all, by the continuous negotiation of strategic care actions capable of expanding the network. This process has been enhanced by social entrepreneurship, which has presented itself as a new organizational trend capable of instigating new technologies and healthcare actions to reach a larger number of people, with greater effectiveness and at a lower cost. (SILVA; MACHADO, 2018).

\section{FINAL CONSIDERATIONS}

The interventions allowed the expansion of the possibilities of healthy living of children of mothers who work in recycling, considering the improvement of theoretical and practical themes and the social empowerment of the mothers.

This study has its importance, as it was possible to identify that the mothers who work in recycling are not able to promote the healthy living of their children due to the excessive workload and insufficient income, leading to the weakening of the bond between mother and child, early weaning, and maternal absence.

In this sense, health professionals must have an entrepreneurial view of the vulnerabilities to which these mothers and children are exposed so that it is possible to develop health education strategies that will promote quality of life and offer them alternatives since the absence is not a choice, but a necessity.

It is believed that the issue addressed is extremely relevant and that it can have a great impact on the opinion of professionals of health and society because it exposes all the difficulties that these mothers face in their lives. Therefore, it is expected that these data can contribute to change the health care and healthy living of the children of mothers who work in recycling and who play a very important social role.

\section{REFERÊNCIAS}

BACKES, D. S.; ZAMBERLAN, C.; COLOMÉ, J.; SOUZA, M. T.; MARCHIORI, M. T.; ERDMANN, A. L.; MAYA, A. M. S. Systemic interactivity between the interdependent concepts of nursing care. In: Aquichan. v. 16, n. 1, p. 24-31, 2016. Available at: https://bit.ly/3kZ7ukr.

BACKES, D. S.; ILA, S.; WEISSHEIMER, A. S.; HALBERSTADT, B. M. K.; MEGIER, E. R.; MACHADO, R. Socially entrepreneurial activities in nursing: Contributions to health/ healthy living. In: Anna Nery School Nursing Magazine, v. 20, n.1, p. 77-82, 2016. Available at: https://bit.ly/397mY3k. 
BARDIN, L. Content analysis. Lisbon: Editions 70, 2011.

BRASÍLIA. National Health Promotion Policy. Ministry of Health, 2010.

COELHO A. P. F.; BECK, C. L.C.; FERNANDES, M. N. S.; SILVA, R. M.; REIS, D. A. M. Work organization in recycling cooperatives: implications for the health of a waste picker. In: Cogitare Nursing Magazine, v. 21, n. 1, 2016. Available at: https://bit.ly/372yAlv.

CORREIA, J. N., ANDRADE, C. A. F., LIMA, N. B. Garbage and recycling: the environmental perception of students from public and private schools in the municipality of Bom Jesus do Itabapoana (RJ). 2016. Available at: https://bit.ly/3pV5JZi.

COSTA, V. L.; ANDRADE, B. B. S. Difficulties and challenges of lactating mothers in the labor Market. In: Mosaic Magazine. v. 10, n. 1, p. 39-5, 2019. Available at: https://bit.ly/3frceOn.

CUNHA, A. J. L. A., LEITE, A. J. M., ALMEIDA, I. S. Pediatrician's performance in the child's first Thousand days: the search for healthy nutrition and development. In: J. Pediatr. (Rio J.), v. 91, n. 6, supl. 1, p. S44-S51, 2015. Available at: https://bit.ly/36WefOU.

DAlCIN, C. B., BACKES, D. S., DOTTO, J. I., SOUZA, M. H. T., MORESCHI, C., BUSCHER. A. Social health determinants that influence the process of healthy living in a vulnerable community. In: Nursing journal UFPE, v. 10, n. 6, p. 1963-1970, 2016.

DIAS, Against waste: the workshop developed during the Tocantins operation that brought together healthy food and recuse of food. In: Interdisciplinary Journal of Teaching, Research and Extension. v. 5, n. 1, p. 590-599, 2017.

FRANCO, M. A. Pedagogy of action research. In: Education Research. v. 31, n. 3, p. 483-502, 2005. Available at: https://bit.ly/3nTRGkz.

LIMA, A. P. C.; NASCIMENTO, D. S.; MARTINS, M. M. F. The practice of breastfeeding and the factors that lead to early weaning: an integrative review. In: Journal Of Health And Biological Sciences. Fortaleza, p. 189-196, 2018. Available at: https://bit.ly/3fyAAGg. 
LOMBA, M. L. L. F.; TOSON, M.; WEISSHEIMER, A. S.; BACKES, M. T. S.; BÜSCHER, A., BACKES, D. S. Social entrepreneurship: translations of knowledge and practices among nursing students in Brazil. In: Magazine Nurse, v. serIV, n. 19, p. 107-115, 2018. Available at: https://bit.ly/ 2J38EOH.

Ministry of Health. Food guide for the Brazilian population. 2. ed. In: Primary Care Notebooks, n. 23. 2015.

Ministry of Health. Child's Health: Breastfeeding and Complementary Food. 2. ed. In: Primary Care Notebooks, $n^{\circ}$ 23. 2015. Available at: https://bit.ly/3pUNrqY.

RODRIGUES, A. E. Experiences of children born to recyclable material collectors: implications for nursing. Federal University of Santa Maria, Health Sciences Center, Graduate Nursing ProgramMaster's thesis, 2017. Available at: https://bit.ly/3pQevaZ.

ROLLINS, N.C.; BHANDARI, N.; HAJEEBHOY, N.; HORTON, S.; LUTTER, C. K.; MARTINES, J. C.; PIWOZ, E. G.; RICHTER, L. M.; VICTORA, C. G. Lancet Breastfeeding Series Group. Why invest, and what it will take to improve breastfeeding practices? In: Lancet. v. 387, n. 10017, p. 491-504, 2016. Available at: https://bit.ly/3kXqoZ0.

SANTOS, P. P.; SCHEID, M. M. A. Importance of exclusive breastfeeding in the first six months of life to promote the health of the mother and baby. In: J Health Sci Inst. V. 37, n. 3, p. 276-280, 2019. Available at: https://bit.ly/36ZrEFX.

SILVA, G. F.; MACHADO, J. A. Knowledge in dialogue: the construction of a teacher training program in a municipal school system. In: Iberoamericana Revista de Educación. v. 77, n. 2, p. 95-114, 2018. Available at: https://bit.ly/3kX7nG1. 
